\title{
EFFECT OF STORAGE CONDITION AND PACKAGE TYPE ON THE QUALITY OF GARLIC DURING STORAGE
}

Doha M. Ibrahim*, Adel H. Bahnasawy** and El-Sayed G. Khater *** ABSTRACT

The main aim of this work was to study the effect of storage system (cold, ventilated and traditional) and package type on the quality of garlic during storage. The results indicated that, the total accumulated weight loss increases with increasing the storage period. Storage system had a great effect on the losses, where, the traditional storage system recorded was $36.89 \%$ compared with 11.47 and $12.33 \%$ for the garlic stored in the cold and ventilated systems. The garlic stored in plastic bags recorded the highest accumulated weight loss (14.00\%) when stored at ventilated storage system while the same package recorded the lowest weight losses (9.75\%) when stored in the cold storage. The highest value of accumulated moisture loss (7.30\%) was recorded by the garlic bulbs stored in clothes bags, while the lowest value of accumulated moisture loss $(5.18 \%)$ was recorded for the garlic stored in plastic bags. Sprouting percent ranged from 14.00 to $21.79 \%$ where the cold storage system recorded the lowest percentage, and the traditional system recorded the highest sprouting. Sprouting ranged from 17.53 to $24.86 \%$ at ventilated system storage. The highest value of empty blubs percentage of garlic (11.03\%) was recorded by the garlic bulbs stored in plastic bags under ventilated storage system, while the lowest value of empty blubs percentage of garlic $(2.15 \%)$ was recorded for the garlic stored in plastic bags under cold storage system.

Keywords: garlic storage - ventilated storage - cold storage - sprouting - empty bulbs - chemical composition

\footnotetext{
* Graduate Student of Agric. Eng. Dep., Fac. of Agric., Benha Univ., Egypt

** Professor of Agric. Eng., Fac. of Agric., Benha Univ., Egypt *** Lecturer of Agric. Eng., Fac. of Agric., Benha Univ., Egypt
} 


\section{INTRODUCTION}

arlic (Allium sativum L.) is one of the most important vegetables throughout the world with a total harvested area of 1437.690 ha and an annual production of 24255.303 tons of dry bulbs (FAO, 2013). The importance of garlic is due to its use not only for culinary but also for therapeutic and medicinal purposes in both traditional and modern medicine. It is consumed either as raw vegetable (fresh leaves or dried cloves), or after processing in the form of garlic oil, garlic extracts and garlic powder with differences in chemical composition and bioactive compounds content between the various forms (Lanzotti et al., 2014). Storage time is an involved and pivotal functional determinant for the garlic bioactive properties. As previously highlighted, antioxidant capacity of garlic cloves was maximum after 8 weeks of storage at $20 \pm 2$ ${ }^{\circ} \mathrm{C}$, whereas for organosulfur compounds and polyphenols, the maximum content was observed between 6 and 8 weeks of storage, followed by a significant decrease after that time period (Fei et al., 2015). Cantwell (2004) has pointed out that garlic can be stored at room temperature (20$30{ }^{\circ} \mathrm{C}$ ) for 1 or 2 months. However, the bulbs eventually lose their firmness and become spongy and discolored due to water loss. Dormancy ends quickly in garlic stored at temperatures between 5 and $18{ }^{\circ} \mathrm{C}$; the optimum temperature is from -1 to $0{ }^{\circ} \mathrm{C}$. White and purple garlic is harvested in the Bajio region of Mexico from February to August and then stored at room temperature. A complete study of quality changes under different conditions and how these conditions interact to determine the shelf life of the product has been lacking, nor have objective parameters to predict shelf life been determined. Six batches of 360 bulbs of garlic (Allium sativum L.) cv. Perla were stored for 190 days at $0{ }^{\circ} \mathrm{C}$ and $70 \%$ relative humidity $(\mathrm{RH}), 5,20,30{ }^{\circ} \mathrm{C}$, and at room temperature (RT) $\left(17.7 \pm 7{ }^{\circ} \mathrm{C}\right)$. The weight loss, subjective firmness of the bulbs, clove penetration resistance, hue value, internal sprouting index, soluble solids and dry matter content of the cloves were recorded periodically. The weight loss and internal sprouting index had a negative correlation on the subjective firmness, penetration resistance, and hue of the cloves. Storage at $5,20{ }^{\circ} \mathrm{C}$, and RT induced sprouting, and subsequent growth influenced a loss of firmness and color. Complete sprouting (>100\%) induced a weight loss of $9-11 \%$ at these temperatures. To maintain an 
adequate safety margin for marketing, we propose an internal sprouting index of $50 \%$ to determining the effective shelf life of garlic cv. 'Perla'. In accordance with this criterion and in conditions studying, shelf life at 0 ${ }^{\circ} \mathrm{C}$ was 155 days; at $5{ }^{\circ} \mathrm{C}$ and $\mathrm{RT}$ it was 80 days; and at $20^{\circ} \mathrm{C}$ it was 60 days. These results lead us to conclude that it is possible to estimate the shelf life of garlic using the internal sprouting index (Vázquez-Barrios $\boldsymbol{e t}$ al., 2006). Veríssimo et al. (2010) observed that the antioxidant potential of garlic decreases, with the increasing temperature. Furthermore, Atashi et al., (2011) by assessing the variations on the chlorophyll, carbohydrates, amylase and invertase enzymes contents in garlic under low temperatures, they observed qualitative and quantitative differences on the sugar contents of garlic, which consequently stimulated its sprouting. Garlic losses during storage represent a great loss on the national level and affects the price stability during the year, which are due to weight losses, sprouting and emptiness of bulbs, therefore, the main aim of this study is to reduce/minimize these losses, this will be achieved by studying the effect of storage condition and package type on these losses during storage.

\section{MATERIALS AND METHODS}

The main objective of the present study is to study the effect of storage conditions and package type on the quality of garlic during storage. The experiment was carried out at Agricultural and Bio-Systems Engineering Department Faculty of Agriculture Moshtohor, Benha University, Egypt, during 2017 season.

\subsection{Materials:}

\subsubsection{Garlic:}

The garlic was brought from the local market, at the beginning of the season, 2017.

\subsubsection{Storage conditions:}

The garlic blubs were stored using different systems as follows:-

\section{- Traditional system.}

Garlic was placed in pile and left in the open field Two hundred kilograms. (200 kg) garlic cloves were folded into a pile.

\section{Ventilated storage system.}

Garlic was folded into different packages in room was air at ambient temperature. Air blower (Model C.C.P. Parma - Flow Rate 110 L 
$\mathrm{h}^{-1}$ - RPM 2800 - Power $300 \mathrm{~W} 220 \mathrm{~V} 50 \mathrm{~Hz}$, Italy) for moving air in the system.

\section{Cold system.}

Garlic was folded into different packages in refrigeration room. Refrigeration room used in this study has dimensions of $3.0 \mathrm{~m}$ length, 3.0 $\mathrm{m}$ in width and $3.0 \mathrm{~m}$ height. It made of prefabricated insulated panels of thickness of $60 \mathrm{~mm}$. The panels insulation are covered with precoated stainless steel sheet on both sides. Cooling unit (Model Egypt Nile Range temperature $0-40{ }^{\circ} \mathrm{C}-\mathrm{RPM} 2800$ - Power 2 hp 380V 50Hz, Italy) for control air temperature and mist system increasing relative humidity of air.

\subsubsection{Package types:}

The garlic was stored at three different package types as follows: -

\section{Perforated cardboard.}

$2.0 \mathrm{~kg}$ garlic was folded into a perforated cardboard package. The dimensions of perforated cardboard package are $30 \mathrm{~cm}$ long, $20 \mathrm{~m}$ wide and $20 \mathrm{~cm}$ high.

\section{Plastic.}

$2.0 \mathrm{~kg}$ garlic was folded into a plastic package. The volume of plastic package is $10 \mathrm{~L}$.

\section{Clothes.}

$2.0 \mathrm{~kg}$ garlic was folded into a clothes package. The volume of clothes package is $10 \mathrm{~L}$.

\subsection{Methods:}

\subsubsection{Experimental design:}

The treatments were arranged in a split plot design in three replications. Table (1) shows the experimental design.

Table (1): The experimental design.

\begin{tabular}{||l|c|l|}
\hline Variables & Levels & Variables Levels \\
\hline \multirow{3}{*}{ Storage conditions } & \multirow{3}{*}{3} & Traditional system \\
\cline { 3 - 3 } & & Ventilated system \\
\cline { 3 - 3 } & & Cold system \\
\hline \multirow{2}{*}{ Package types } & \multirow{3}{*}{3} & Perforated cardboard \\
\cline { 3 - 3 } & & Plastic \\
\cline { 3 - 3 } & & Clothes \\
\hline
\end{tabular}




\subsubsection{Measurements:}

Temperature and relative humidity readings were recorded every hour at various locations in the storage systems. Temperature and relative humidity were recorded by using a HOBO Data Logger (Model HOBO U12 Temp/RH/Light-Range -20 to $70^{\circ} \mathrm{C}$ and 5 to $95 \%$ RH, USA). Garlic samples were taken randomly from different systems every 10 days to determine the total weight losses.

Samples were taken monthly to determine the moisture loss. Garlic samples were weighed every 10 day during storage. Garlic samples were dried using drying oven at $105{ }^{\circ} \mathrm{C}$ until a constant weight was obtained. The moisture content was calculated as follows:

$$
M \mathrm{C}=\frac{\mathrm{M}_{\mathrm{wet}}-M_{d r y}}{\mathrm{M}_{\mathrm{dry}}} \times 100
$$

Where:

$\mathrm{MC}$ is the moisture content (\% wb)

$\mathrm{M}_{\text {wet }}$ is the wet mass $(\mathrm{kg})$

$\mathrm{M}_{\text {dry }}$ is the dry mass $(\mathrm{kg})$

Garlic sprouting and empty bulbs percentages were determined by the end of storage period. Total contents of macro elements were evaluated after being digested according to Chapman and Partt (1961). Nitrogen was determined by Kjeldahl digestion apparatus (Bremmer and Mulvaney, 1982). Potassium, calcium and magnesium were determined by Photofatometer (Model Jenway PFP7 - Range 0 - $160 \mathrm{mmol} \mathrm{L}^{-1}$, USA) and phosphorus (P) was determined colorimetrically following the Murphy and Riley (1962) method. Protein, fat, fibers and ash content were determined according to the method of AOAC (1990).

\subsection{Storage conditions:}

\section{RESULTS AND DISCUSSION}

Figures ( 1 and 2 ) show the average of temperature and relative humidity for the storage systems (cold, ventilated and traditional) under study. The average temperature ranged from 4.0 to $5.8,30.0$ to 33.2 and 18.4 to 34.8 ${ }^{\circ} \mathrm{C}$ for the cold storage, ventilated and traditional storage systems, respectively. It can be seen that the temperature in the traditional system 
fluctuated from $34{ }^{\circ} \mathrm{C}$ during the day time to less than $18{ }^{\circ} \mathrm{C}$ during the night time. The relative humidity values ranged from 25.3 to $61.1,43.2$ to 58.7 and 26.1 to $99.8 \%$, for the same pervious order during the storage period.

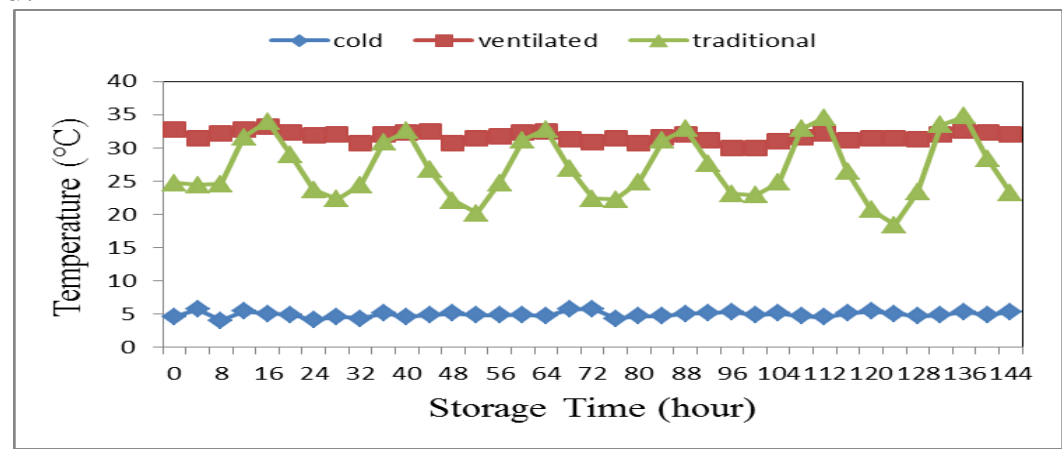

Figure (1): The average temperature for the storage systems.

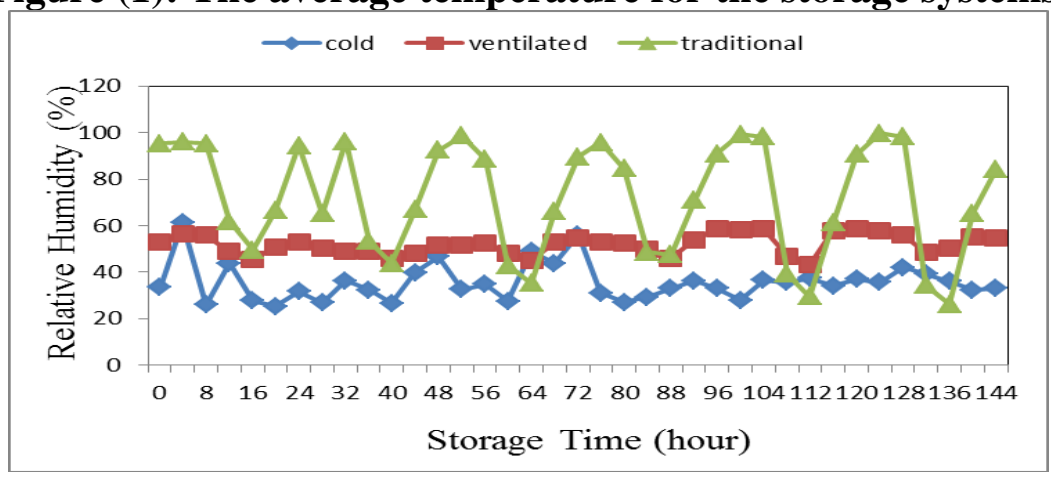

Figure (2): The average relative humidity for the storage systems.

3.2. Effect of storage conditions and packaging type on the accumulated losses of garlic moisture during the storage:

Table (2) shows the effect of different storage conditions (cold, ventilated and traditional) and different packages (clothes, plastic and perforated cardboard) on the accumulated moisture loss of garlic during the storage. The results indicated that the accumulated moisture loss of garlic increases with increasing storage period. It could be seen the accumulated moisture loss increased from 1.06 to $7.30,1.05$ to 7.22 and 0.97 to $6.79 \%$ for garlic stored in clothes, plastic and cardboard packages, respectively under the cold storage system, when the storage time increased from 1 to 6 months. 
Table (2): The effect of different storage conditions and different packages on the accumulated moisture loss of garlic during the storage.

\begin{tabular}{|c|c|c|c|c|c|c|c|}
\hline \multirow{4}{*}{$\begin{array}{l}\text { Storage } \\
\text { Time } \\
\text { (month) }\end{array}$} & \multicolumn{7}{|c|}{ Storage System } \\
\hline & \multicolumn{3}{|c|}{ Cold Storage } & \multicolumn{3}{|c|}{ Ventilated Storage } & \multirow{2}{*}{ Traditiona } \\
\hline & Clothes & plastic & Cardboard & Clothes & Plastic & cardboard & \\
\hline & \multicolumn{7}{|c|}{ Accumulated Moisture Losses, \% } \\
\hline 1 & 1.06 & 1.05 & 0.97 & 0.89 & 1.08 & 0.83 & 0.69 \\
\hline 2 & 2.21 & 2.33 & 2.18 & 1.71 & 1.64 & 1.89 & 1.38 \\
\hline 3 & 3.85 & 3.80 & 3.47 & 2.85 & 2.46 & 2.63 & 2.17 \\
\hline 4 & 5.14 & 5.05 & 4.95 & 3.55 & 3.29 & 3.62 & 2.81 \\
\hline 5 & 6.35 & 6.18 & 5.64 & 4.43 & 4.22 & 4.42 & 3.78 \\
\hline 6 & 7.30 & 7.22 & 6.79 & 5.25 & 5.18 & 5.38 & 4.39 \\
\hline
\end{tabular}

In the ventilated system, the accumulated moisture loss increased from 0.89 to $5.25,1.08$ to 5.18 and 0.83 to $5.38 \%$ for garlic stored in clothes, plastic and cardboard packages, respectively, when the storage time increased from 1 to 6 months. The accumulated moisture loss increased from 0.69 to $4.39 \%$ for the garlic stored in the traditional system, when the storage time increased from 1 to 6 months. The results also indicate that the accumulative moisture loss of garlic during storage was increased in cold storage system more than those of room temperature system and traditional system. It could be seen that the accumulated moisture losses of garlic were 7.30, 7.22 and $6.79 \%$ for garlic stored in clothes, plastic and cardboard packages, respectively, at the end of period storage under the cold storage system. While, the accumulated moisture losses of garlic were 5.25, 5.18 and $5.38 \%$ for garlic stored in clothes, plastic and cardboard packages, respectively, at the end of period storage under the ventilated storage system. The moisture content is considered one of the most important factors in maintaining product quality. The rate of water loss from the commodities depends upon the water pressure deficit between the commodity and the surrounding ambient air, which is influenced by the temperature and relative humidity. Concerning the effect of package type, under the cold storage system, the highest value of accumulated moisture loss $(7.30 \%)$ was recorded by the garlic bulbs stored in clothes bags while the lowest value of accumulated moisture loss $(6.79 \%)$ was recorded for the garlic stored in perforated cardboard 
bags. At the ventilated storage system, the highest value of accumulated moisture loss $(5.38 \%)$ was recorded by the garlic bulbs stored in perforated cardboard bags while the lowest value of accumulated moisture loss $(5.18 \%)$ was recorded for the garlic stored in plastic bags. Regression analysis was carried out to find a relation between the accumulated moisture loss and both storage systems and packages type. Equation (2) shows the most appropriate form for the relationship between the accumulated moisture losses as a function of storage period under different packages type at different storage systems. The constants of these equations and coefficient of determination are listed in Table (3).

$$
M L=a+\mathrm{bT}
$$

Where:-

WL is the accumulated moisture loss of garlic (\%)

$\mathrm{T}$ is the storage period (month)

Table (3): The constants $a, b$ and coefficient of determination for accumulated moisture loss at the different storage systems and the different packages type.

\begin{tabular}{|c|c|c|c|c|}
\hline Storage System & Packages & \multicolumn{2}{|c|}{ Constants } & \multirow{2}{*}{ Type } \\
\cline { 2 - 5 } & Ty & $\mathrm{A}$ & $\mathrm{b}$ & $\mathrm{R}^{2}$ \\
\hline \multirow{3}{*}{ Cold Storage } & Clothes & -0.173 & 1.283 & 0.993 \\
\cline { 2 - 5 } & Plastic & -0.093 & 1.247 & 0.996 \\
\cline { 2 - 5 } & Carton & -0.096 & 1.170 & 0.991 \\
\hline Ventilated Storage & Clothes & 0.047 & 0.876 & 0.996 \\
\cline { 2 - 5 } & Plastic & 0.071 & 0.831 & 0.992 \\
\cline { 2 - 5 } & Carton & -0.005 & 0.895 & 0.998 \\
\hline Traditional Storage & & -0.097 & 0.753 & 0.997 \\
\hline
\end{tabular}

3.3. Effect of storage conditions and packaging type on the accumulated weight losses of garlic during the storage:

Table (4) shows the effect of different storage conditions (cold, ventilated and traditional) and different packages (clothes, plastic and perforated cardboard) on the accumulated weight loss of garlic during the storage. The results indicated that the accumulated weight loss of garlic increases with increasing storage period. It could be seen the accumulated weight loss increased from 0.35 to $13.75,0.15$ to 9.75 and 0.50 to $10.90 \%$ for garlic stored in clothes, plastic and cardboard packages, respectively 
under the cold storage system, when the storage time increased from 10 to 160 days. In the ventilated system, the accumulated weight loss increased from 0.70 to $12.15,0.65$ to 14.00 and 0.75 to $10.50 \%$ for garlic stored in clothes, plastic and cardboard packages, respectively, when the storage time increased from 10 to 160 days. The accumulated weight loss increased from 2.47 to $36.89 \%$ for the garlic stored in the traditional system, when the storage time increased from 10 to 160 days. Generally, the higher storage temperature, the higher vapor pressure deficit, the higher weight losses of fruits. These results were in agreement with those obtained by Khater and Bahnasawy (2016).

Table (4): The effect of different storage conditions and different packages on the accumulated weight loss of garlic during the storage.

\begin{tabular}{|c|c|c|c|c|c|c|c|}
\hline \multirow{4}{*}{$\begin{array}{c}\text { Storage } \\
\text { Time } \\
\text { (day) }\end{array}$} & \multicolumn{7}{|c|}{ Storage System } \\
\hline & \multicolumn{3}{|c|}{ Cold Storage } & \multicolumn{3}{|c|}{ Ventilated Storage } & \multirow{2}{*}{ Traditional } \\
\hline & clothes & plastic & Cardboard & clothes & plastic & cardboard & \\
\hline & \multicolumn{7}{|c|}{ Accumulated Weight Losses, $\%$} \\
\hline 10 & 0.35 & 0.15 & 0.50 & 0.70 & 0.65 & 0.75 & 2.47 \\
\hline 20 & 0.75 & 0.50 & 1.00 & 1.25 & 1.15 & 1.10 & 4.91 \\
\hline 30 & 1.25 & 0.75 & 1.60 & 1.75 & 1.85 & 1.60 & 7.32 \\
\hline 40 & 1.90 & 1.15 & 2.00 & 2.50 & 2.50 & 2.15 & 9.71 \\
\hline 50 & 2.65 & 1.65 & 2.60 & 3.00 & 3.35 & 2.65 & 12.08 \\
\hline 60 & 3.15 & 2.10 & 3.00 & 3.60 & 4.15 & 3.25 & 14.43 \\
\hline 70 & 3.90 & 2.65 & 3.60 & 4.35 & 5.10 & 3.85 & 16.77 \\
\hline 80 & 4.75 & 3.85 & 4.10 & 5.00 & 5.85 & 4.35 & 19.09 \\
\hline 90 & 5.75 & 4.35 & 4.85 & 5.75 & 6.65 & 4.90 & 21.39 \\
\hline 100 & 6.85 & 5.35 & 5.50 & 6.65 & 7.75 & 5.75 & 23.66 \\
\hline 110 & 7.75 & 5.90 & 6.25 & 7.60 & 8.50 & 6.50 & 25.92 \\
\hline 120 & 9.00 & 6.50 & 7.10 & 8.60 & 9.65 & 7.35 & 28.15 \\
\hline 130 & 10.35 & 7.10 & 8.10 & 9.60 & 10.65 & 8.10 & 30.36 \\
\hline 140 & 11.00 & 7.85 & 8.75 & 10.35 & 11.65 & 8.75 & 32.56 \\
\hline 150 & 12.60 & 8.75 & 10.00 & 11.25 & 12.65 & 9.60 & 34.73 \\
\hline 160 & 13.75 & 9.75 & 10.90 & 12.15 & 14.00 & 10.50 & 36.89 \\
\hline
\end{tabular}

Concerning the effect of package type, under the cold storage system, the highest value of accumulated weight loss $(13.75 \%)$ was recorded by the garlic bulbs stored in clothes bags while the lowest value of accumulated 
weight loss $(9.75 \%)$ was recorded for the garlic stored in plastic bags. At the ventilated storage system, the highest value of accumulated weight loss $(14.00 \%)$ was recorded by the garlic bulbs stored in plastic bags while the lowest value of accumulated weight loss $(10.50 \%)$ was recorded for the garlic stored in carton (perforated cardboard) bags. This trend was in agreement with the results obtained by Bahnasawy and Dabee (2006).

Regression analysis was carried out to find a relation between the accumulated weight loss and both storage systems and packages type. Equation (3) shows the most appropriate form for the relationship between the accumulated weight losses as a function of storage period under different packages type at different storage systems. The constants of these equations and coefficient of determination are listed in Table (5).

$$
W L=a+\mathrm{bT}
$$

Where:-

WL is the accumulated weight loss of garlic (\%)

$\mathrm{T}$ is the storage period (day)

Table (5): The constants $a, b$ and coefficient of determination for accumulated weight loss at the different storage systems and the different packages type.

\begin{tabular}{|c|c|c|c|c||}
\hline \multirow{2}{*}{ Storage System } & \multirow{2}{*}{$\begin{array}{c}\text { Packages } \\
\text { Type }\end{array}$} & \multicolumn{2}{|c|}{ Constants } & \multirow{2}{*}{$\mathbf{R}^{\mathbf{2}}$} \\
\cline { 3 - 4 } & Alothes & -1.711 & 0.091 & 0.978 \\
\hline \multirow{3}{*}{ Cold Storage } & Plastic & -1.284 & 0.065 & 0.984 \\
\cline { 2 - 4 } & Carton & -0.769 & 0.068 & 0.980 \\
\hline \multirow{3}{*}{ Ventilated Storage } & Clothes & -0.708 & 0.078 & 0.990 \\
\cline { 2 - 4 } & Plastic & -0.938 & 0.089 & 0.993 \\
\cline { 2 - 4 } & Carton & -0.483 & 0.065 & 0.989 \\
\hline Traditional Storage & & 0.523 & 0.229 & 0.999 \\
\hline
\end{tabular}

3.4. Effect of storage systems and packaging type on the garlic sprouting during the storage:

Figure (3) shows the effect of different storage systems (cold, ventilated and traditional) and different packages (clothes, plastic and perforated cardboard) on the sprouting percentage of garlic during the storage. The results indicated that the garlic sprouting were $21.79 \pm 2.25,14.62 \pm 2.09$ and $14.00 \pm 3.07 \%$ for garlic stored in clothes, plastic and cardboard 
packages, respectively under the cold storage system at the end of period storage. In the ventilated storage, the garlic sprouting were $17.53 \pm 3.07$, $24.86 \pm 2.44$ and $18.16 \pm 1.81 \%$ for garlic stored in clothes, plastic and cardboard packages, respectively, while, it was $20.63 \pm 5.97 \%$ for garlic stored under traditional system.

Concerning the effect of package type, under the cold storage system, the highest value of sprouting percentage of garlic $(21.79 \%)$ was recorded by the garlic bulbs stored in clothes bags while the lowest value of sprouting percentage of garlic $(14.00 \%)$ was recorded for the garlic stored in perforated cardboard bags. At the ventilated storage system, the highest value of sprouting percentage of garlic $(24.86 \%)$ was recorded by the garlic bulbs stored in plastic bags while the lowest value of sprouting percentage of garlic $(17.53 \%)$ was recorded for the garlic stored in clothes bags.

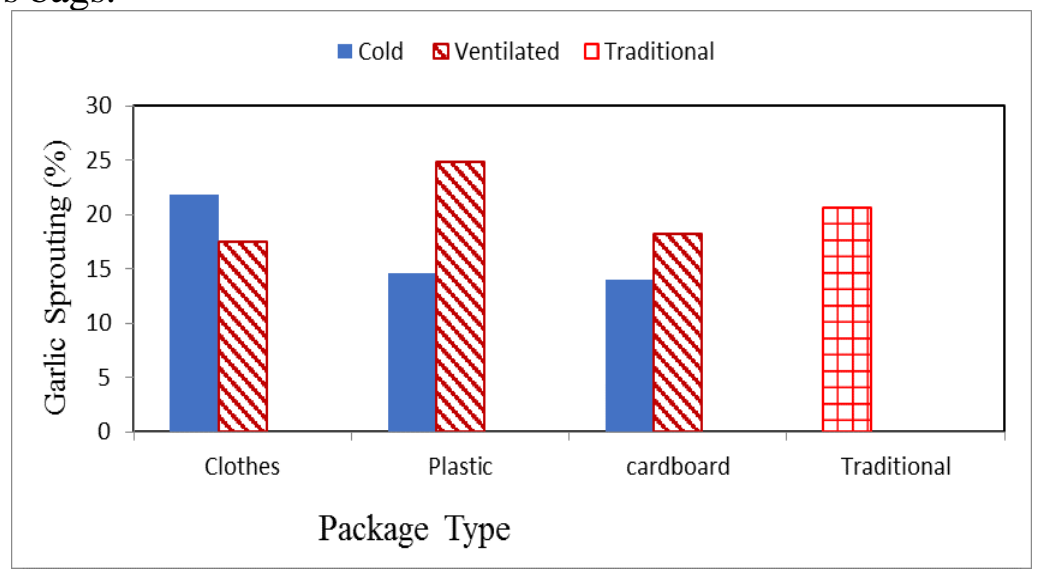

Figure (3): The effect of different storage systems and different packages on the sprouting of garlic during the storage.

\subsection{Effect of storage systems and packaging type on the garlic empty bulb percentage during the storage:}

Figure (4) show the effect of different storage systems (cold, ventilated and traditional) and different packages (clothes, plastic and perforated cardboard) on the empty blub percentage of garlic during the storage. The results indicated that the garlic empty were $2.39 \pm 0.82,2.15 \pm 0.89$ and $3.18 \pm 0.72 \%$ for garlic stored in clothes, plastic and cardboard packages, respectively under the cold storage system at the end of period storage. In the ventilated storage, the garlic empty were $8.80 \pm 1.32,11.03 \pm 1.26$ 
and $10.25 \pm 1.37 \%$ for garlic stored in clothes, plastic and cardboard packages, respectively, while, it was $7.92 \pm 1.05 \%$ for garlic stored under traditional system.

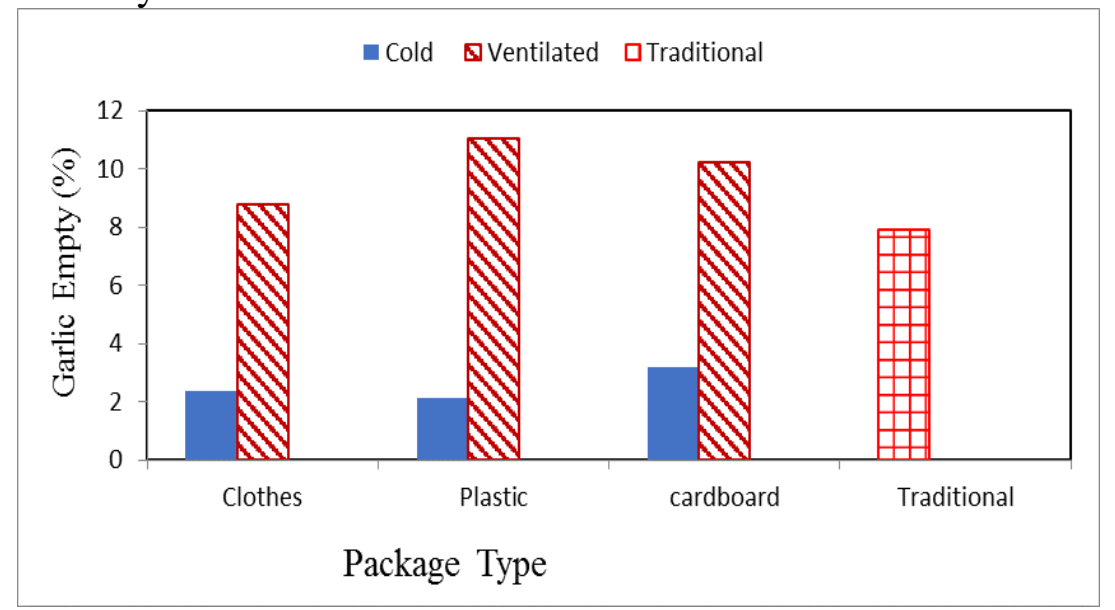

Figure (4): The effect of different storage systems and different packages on the empty bulb of garlic during the storage.

Concerning the effect of package type, under the cold storage system, the highest value of empty blubs percentage of garlic $(3.18 \%)$ was recorded by the garlic bulbs stored in perforated cardboard bags while the lowest value of empty blubs percentage of garlic $(2.15 \%)$ was recorded for the garlic stored in plastic bags. At the ventilated storage system, the highest value of empty blubs percentage of garlic $(11.03 \%)$ was recorded by the garlic bulbs stored in plastic bags while the lowest value of empty blubs percentage of garlic $(8.80 \%)$ was recorded for the garlic stored in clothes bags.

\subsection{Effect of storage system and packaging type on the chemical composition of garlic before and after storage:}

Table (5) shows the effect of storage system and package type on the chemical composition of garlic before and after storage. The results indicate that the nitrogen $(\mathrm{N})$ was increased from 1.71 to $2.28,1.71$ to 1.80 and 1.71 to $2.22 \%$ for garlic stored in clothes, plastic and cardboard packages, respectively under the cold storage system at the end of period storage. In the ventilated storage, the nitrogen $(\mathrm{N})$ was increased from 1.71 to $2.41,1.71$ to 1.72 and 1.71 to $2.41 \%$ for garlic stored in clothes, plastic and cardboard packages, respectively under the cold storage 
system at the end of period storage, while, it was increased from 1.71 to $2.90 \%$ for garlic stored under traditional system.

Table (5): The effect of storage system and package type on the chemical composition of garlic before and after storage.

\begin{tabular}{|c|c|c|c|c|c|c|c|c|}
\hline \multirow{4}{*}{\multicolumn{2}{|c|}{ Element }} & \multicolumn{7}{|c|}{ Storage System } \\
\hline & & \multicolumn{3}{|c|}{ Cooling System } & \multicolumn{3}{|c|}{ Ventilated } & \multirow{2}{*}{$\boxminus: \vec{z} \cong$} \\
\hline & & clothes & Plastic & Cardboard & clothes & Plastic & Cardboard & \\
\hline & & \multicolumn{7}{|c|}{ Chemical Composition, $\%$} \\
\hline \multirow{2}{*}{ Nitrogen } & Before & 1.71 & 1.71 & 1.71 & 1.71 & 1.71 & 1.71 & 1.71 \\
\hline & After & 2.28 & 1.80 & 2.22 & 2.41 & 1.72 & 2.41 & 2.90 \\
\hline \multirow{2}{*}{ Phosphorus } & Before & 0.18 & 0.18 & 0.18 & 0.18 & 0.18 & 0.18 & 0.18 \\
\hline & After & 0.10 & 0.16 & 0.13 & 0.12 & 0.16 & 0.11 & 0.13 \\
\hline \multirow{2}{*}{ Potassium } & Before & 0.69 & 0.69 & 0.69 & 0.69 & 0.69 & 0.69 & 0.69 \\
\hline & After & 0.71 & 1.03 & 1.03 & 0.80 & 1.18 & 0.72 & 0.93 \\
\hline \multirow{2}{*}{ Calcium } & Before & 0.20 & 0.20 & 0.20 & 0.20 & 0.20 & 0.20 & 0.20 \\
\hline & After & 0.21 & 0.31 & 0.25 & 0.26 & 0.32 & 0.21 & 0.24 \\
\hline \multirow{2}{*}{ Magnesium } & Before & 0.09 & 0.09 & 0.09 & 0.09 & 0.09 & 0.09 & 0.09 \\
\hline & After & 0.03 & 0.05 & 0.05 & 0.04 & 0.05 & 0.04 & 0.04 \\
\hline \multirow{2}{*}{ Protein } & Before & 10.69 & 10.69 & 10.69 & 10.69 & 10.69 & 10.69 & 10.69 \\
\hline & After & 14.25 & 11.25 & 13.88 & 15.06 & 10.75 & 15.06 & 18.13 \\
\hline \multirow{2}{*}{ Fat } & Before & 0.34 & 0.34 & 0.34 & 0.34 & 0.34 & 0.34 & 0.34 \\
\hline & After & 0.33 & 0.32 & 0.33 & 0.30 & 0.31 & 0.32 & 0.29 \\
\hline \multirow{2}{*}{ Ash } & Before & 1.63 & 1.63 & 1.63 & 1.63 & 1.63 & 1.63 & 1.63 \\
\hline & After & 1.66 & 1.65 & 1.66 & 1.66 & 1.67 & 1.66 & 1.67 \\
\hline \multirow{2}{*}{ Fiber } & Before & 2.13 & 2.13 & 2.13 & 2.13 & 2.13 & 2.13 & 2.13 \\
\hline & After & 2.18 & 2.19 & 2.18 & 2.20 & 2.18 & 2.19 & 2.21 \\
\hline \multirow{2}{*}{ Carbohydrate } & Before & 27.53 & 27.53 & 27.53 & 27.53 & 27.53 & 27.53 & 27.53 \\
\hline & After & 31.83 & 31.98 & 31.61 & 32.23 & 32.29 & 32.41 & 33.05 \\
\hline
\end{tabular}

The results also, indicate that the phosphorus $(\mathrm{P})$ was decreased from 0.18 to $0.10,0.18$ to 0.13 and 0.18 to $0.13 \%$ for garlic stored in clothes, plastic and cardboard packages, respectively under the cold storage system at the end of period storage. In the ventilated storage, the phosphorus $(\mathrm{P})$ was decreased from 0.18 to $0.12,0.18$ to 0.16 and 0.18 to $0.11 \%$ for garlic stored in clothes, plastic and cardboard packages, respectively under the cold storage system at the end of period storage, while, it was decreased 0.18 to $0.13 \%$ for garlic stored under traditional system. The result revealed that potassium $(\mathrm{K})$ was increased from 0.69 to $0.92,0.69$ to 0.90 $\%$ for both cold and ventilated storage, respectively and it increased from 0.69 to $0.93 \%$ for the garlic stored traditionally. The calcium $(\mathrm{Ca})$ was increased from 0.20 to $0.26,0.20$ to 0.79 and 0.20 to $0.24 \%$ for garlic stored under cold, ventilated and traditional storage, respectively. The magnesium $(\mathrm{Mg})$ was decreased from decreased from 0.09 to $0.03,0.09$ 
to 0.05 and 0.09 to $0.05 \%$ for garlic stored in clothes, plastic and cardboard packages, respectively under the cold storage system at the end of period storage. In the ventilated storage, the magnesium $(\mathrm{Mg})$ was decreased from 0.09 to $0.04,0.09$ to 0.05 and 0.09 to $0.04 \%$ for garlic stored in clothes, plastic and cardboard packages, respectively under the cold storage system at the end of period storage, while, it was decreased 0.09 to $0.04 \%$ for garlic stored under traditional system. The protein was increased from 10.69 to $14.25,10.69$ to 13.62 and 10.69 to $18.13 \%$ for garlic stored under cold, ventilated and traditional storage, respectively. Fat content was decreased 0.34 to $0.33,0.34$ to 0.31 and 0.34 to $0.29 \%$ for garlic stored under cold, ventilated and traditional storage, respectively. Ash content increased from 1.630 to $1.657,1.630$ to 1.667 and 1.63 to $1.670 \%$ for garlic stored under cold, ventilated and traditional storage, respectively. Fiber was increased from 2.13 to 2.18 and 2.13 to $2.19 \%$ for both cold and ventilated storage systems, respectively and it increased from 2.13 to $2.21 \%$ for the garlic stored traditionally. Garlic content from carbohydrates increased from 27.53 to $31.81,27.53$ to 32.31 $\%$ for both cold and ventilated storage systems, respectively, while it increased from 27.53 to $33.05 \%$ for the traditional storage system.

\section{CONCLUSIONS}

An experimental study was carried out successively to study the effect of storage system and package type on the quality of garlic during storage. The obtained results can be summarized as follows:

- The highest value of accumulated moisture loss (7.30\%) was recorded by the garlic bulbs stored in clothes bags, while the lowest value of accumulated moisture loss $(5.18 \%)$ was recorded for the garlic stored in plastic bags.

- The total accumulated weight loss recorded was $36.89 \%$ for the garlic stored traditionally, compared with 11.47 and $12.33 \%$ for the garlic stored in the cold and ventilated systems. The garlic stored in plastic bags recorded the highest accumulated weight loss $(14.00 \%)$ when stored at ventilated storage system while the same package recorded the lowest weight losses (9.75\%) when stored in the cold storage.

- Sprouting percent ranged from 14.00 to $21.79 \%$ where the cold storage system recorded the lowest percentage, and the traditional 
system recorded the highest sprouting. Sprouting ranged from 17.53 to $24.86 \%$ at ventilated system storage.

- The highest value of empty blubs percentage of garlic (11.03\%) was recorded by the garlic bulbs stored in plastic bags under ventilated storage system, while the lowest value of empty blubs percentage of garlic $(2.15 \%)$ was recorded for the garlic stored in plastic bags under cold storage system.

\section{REFERENCES}

AOAC (Official Methods of Analysis) (1990). Association of official analytical chemists. 5th Edt., 1990 Pub. by the Association of Official Analytical Chemists, Suite 400.

Atashi, S., V. Akbarpour, K. Mashayekhi and S.J. Mousavizadeh (2011). Garlic physiological characteristics from harvest to sprouting in response to low temperature. J. Stored Prod. Postharvest Res., 2: 285 - 291.

Bahnasawy, A.H. and S. A. Dabee (2006). Technological Studies on Garlic Storage. The $1^{\text {st }}$ Conference of the Agricultural Chemistry and Enviroment Protection Society, Ain Shams university, during the period of $5-7$ december, 2006

Bremmer, J. M. and C. S. Mulvaney (1982). Nitrogen-total. In: Page, A.L., Miller, R.H., Keeney, D.R. (Eds.), Methods of Soil Analysis, Part 2. Chemical and Microbiological Properties, second ed., Agronomy series No. 9 ASA, SSSA, Madison, WI, pp. 595-624.

Cantwell, M.I. (2004). Garlic. Recommendations for maintaining postharvest quality. http:/postharvest.ucdavis.edu/Produce/ProduceFacts.

Chapman, H. D. and F. P. Partt (1961). Methods of analysis of soils, plant and water. Cal. Univ., 150-200.

FAO (2013). Production and trade statistics. FAO, Rome, Italy.

Fei, M.L., L.I. Tong, L.I. Wei and L. De Yang, (2015). Changes in antioxidant capacity, levels of soluble sugar, total polyphenol, organosulfur compound and constituents in garlic clove during storage. Industrial Crops and Products, 69: 137-142. 
Khater, E.G. and A.H. Bahnasawy (2016). Watermelon fruits properties as affected by storage conditions. Misr J. Agri. Eng., 33 (1): 101 122.

Lanzotti, V., F. Scala and G. Bonanomi (2014). Compounds from Allium species with cytotoxic and antimicrobial activity. Phytochemistry Reviews, 13: 769 - 791.

Murphy, J. and J.P. Riley (1962). A modified single solution method for determination of phosphate in natural waters. Anal. Chem. Acta, 27: 31-36.

Vázquez-Barrios, M.E, G. López-Echevarría, E. Mercado-Silv, E. Castaño-Tostado and F. León-González (2006). Study and prediction of quality changes in garlic cv. Perla (Allium sativum L.) stored at different temperatures. Scientia Horticulturae, 108(2): 127132.

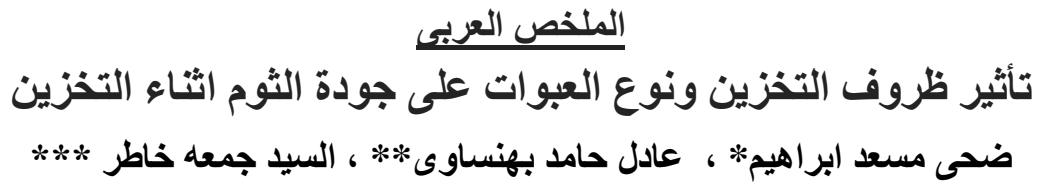

يهدف هذا البحث الى در اسة تأثثر ظروف التخزين ونوع العبوات على جودة الثوم أثناء

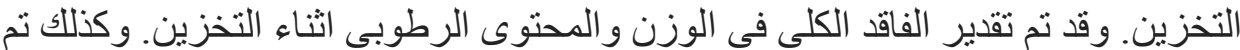

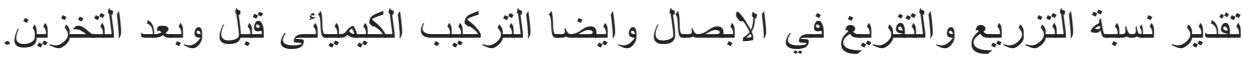

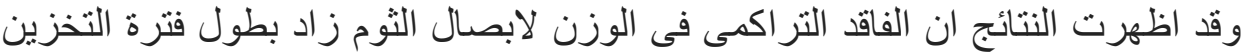

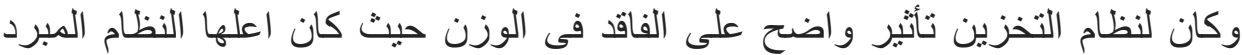

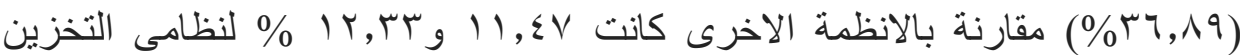

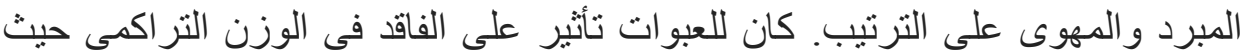
كانت اقلها للعبوات البلاستيك (

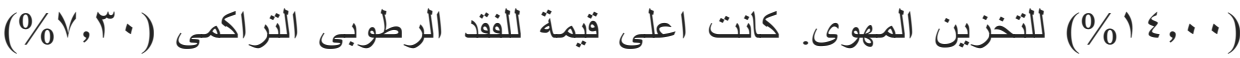

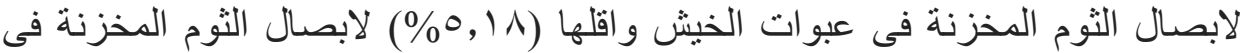

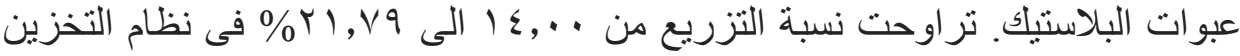

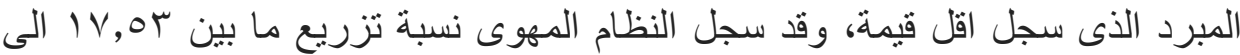

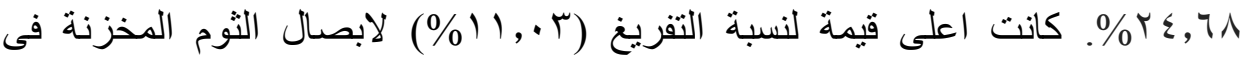

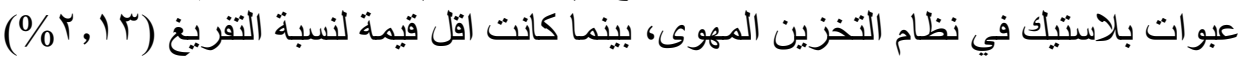
لابصال الثوم المخزنة في عبو ات بلاستيك في نظام التخزين المبرد.

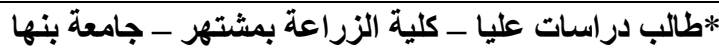

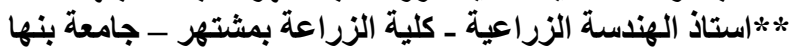

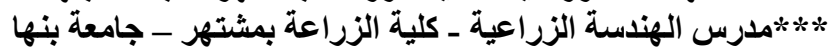

